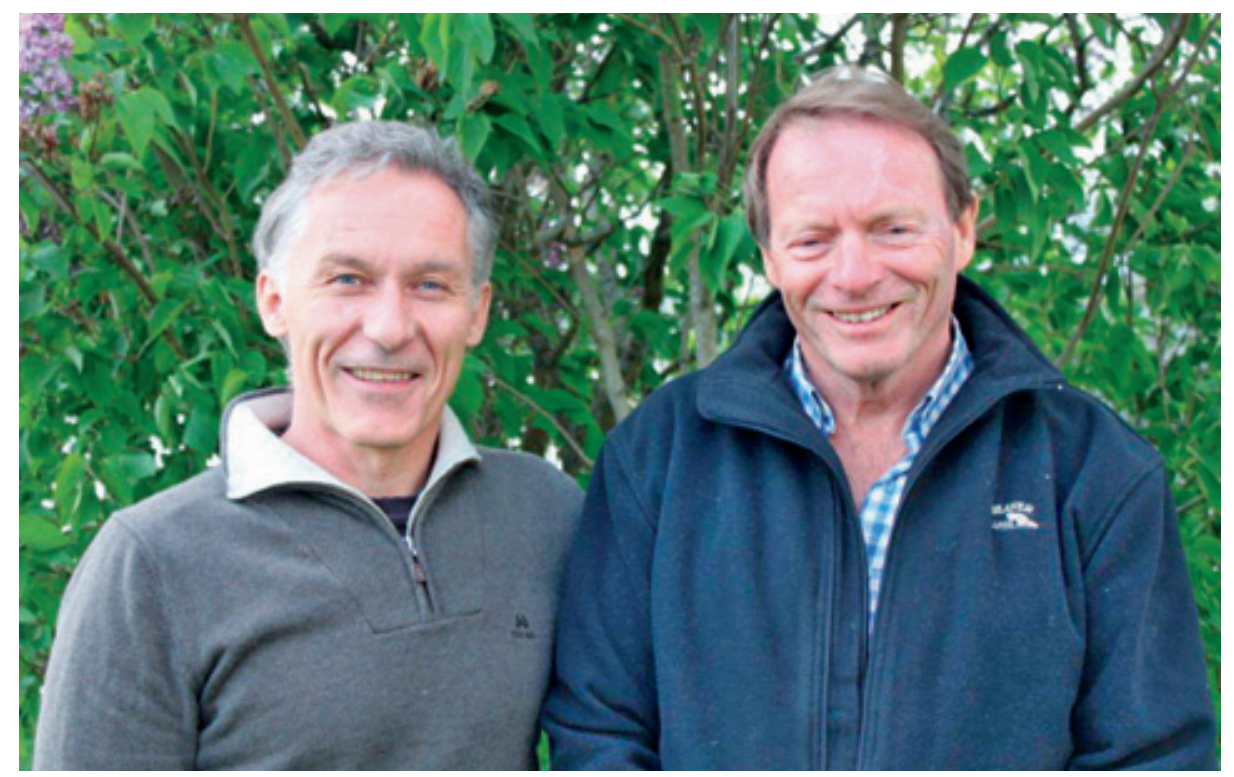

Sigurd Liavaag og Svein Svenningsen. Foto privat
Ordforklaringer

Skulderluksasjon: Foreligger når leddhodet $\emptyset$ verst på overarmen går helt ut av sin plass i skulderskålen. Dette er den hyppigste luksasjonen av store ledd hos mennesker. Traumatisk fremre skulderluksasjon utgjør $95 \%$ av alle skulderluksasjoner. Risikoen er størst når armen er i utadrotert og abdusert stilling, og de hyppigste utløsende årsakene er fallskade eller direkte traume mot skulderen. Insidensen for første gangs skulderluksasjon er ca. 26 per 100000 innbyggere per år.

Intention-to-treat-analyse: Ved behandlingsintensjonsanalyse inkluderes alle som er tiltenkt å starte med en behandling, også de som ikke starter eller ikke fullfører. Dette til forskjell fra per-protokoll-analyse, som tar med bare de som fullfører en spesifikk behandling.

\title{
Behandling av skulderluksasjoner
}

Immobilisering med armen i utadrotert stilling etter primær fremre skulderluksasjon minsker ikke risikoen for residiv. Det viser en ny norsk multisenterstudie.

Det er ikke enighet om hva som er beste behandling for pasienter med en primær fremre traumatisk skulderluksasjon. Anvendt behandling i dag varierer fra fri mobilisering fra første dag til immobilisering $i$ tre uker med armen innadrotert i fatle eller slynge. I 2007 viste en randomisert studie fra Japan gode resultater med en ny behandling, hvor armen ble immobilisert tre uker i utadrotert stilling (1). Nå har norske forskere sammenliknet effekten av immobilisering i innadrotasjon og immobilisering i utadrotasjon ved fremre skulderluksasjon (2).

- Totalt ble 188 pasienter med traumatisk primær fremre skulderluksasjon randomisert til behandling med enten immobilisering i innadrotasjon eller immobilisering i utadrotasjon, sier førsteforfatter Sigurd Liavaag ved Ortopedisk avdeling, Sørlandet sykehus, Arendal. - Vårt primære utfallsmål var ny luksasjon, det vil si residiv, i løpet av to år. Totalt fullførte $98 \%$ av pasientene minst to års oppfølging. Pasientrapportert etterlevelse for immobilisering 16 timer daglig i tre uker var lavere ved innadrotasjon enn ved utadrotasjon, 47,4\% $\operatorname{mot} 67,7 \%$.

Intention-to-treat-analyse viste at residivraten var $24,7 \%$ i gruppen med immobilisering i innadrotasjon og 30,8\% i utadrotasjonsgruppen $(\mathrm{p}=0,36)$. Per-protokoll-analyse hos pasienter som hadde full immobilisering $\mathrm{i}$ tre uker viste heller ingen signifikant forskjell mellom gruppene.
Immobilisering med armen i utadrotert stilling reduserte altså ikke residivraten hos pasienter med første gangs traumatisk fremre skulderluksasjon.

Operativ behandling tilbys vanligvis ikke ved første gangs luksasjon, men i fagmiljøet debatteres det om operasjon bør tilbys unge med høy residivrisiko. Dette er en problemstilling som bør undersøkes i fremtidige studier, sier Sigurd Liavaag.

\section{Forskning på skulderluksasjon}

Artikkelen er skrevet av Sigurd Liavaag, Jens Ivar Brox, Are Hugo Pripp, Martine Enger, Lars Atle Soldal og Svein Svenningsen. Liavaag og Svenningsen arbeider ved Ortopedisk avdeling, Sørlandet sykehus, Arendal. Artikkelen inngår i Liavaags doktoravhandling. Svenningsen og Brox er veiledere. Pasientene ble rekruttert i et samarbeid mellom 11 norske sentre.

\section{Erlend T. Aasheim}

erlend.aasheim@legeforeningen.no Tidsskriftet

\section{Litteratur}

1. Itoi E, Hatakeyama Y, Sato T et al. Immobilization in external rotation after shoulder dislocation reduces the risk of recurrence. A randomized controlled trial. J Bone Joint Surg Am 2007; 10 : 2124-31.

2. Liavaag S, Brox JI, Pripp AH et al. Immobilization in external rotation after primary shoulder dislocation did not reduce the risk of recurrence: a randomized controlled trial. J Bone Joint Surg Am 2011; 93: 897-904.

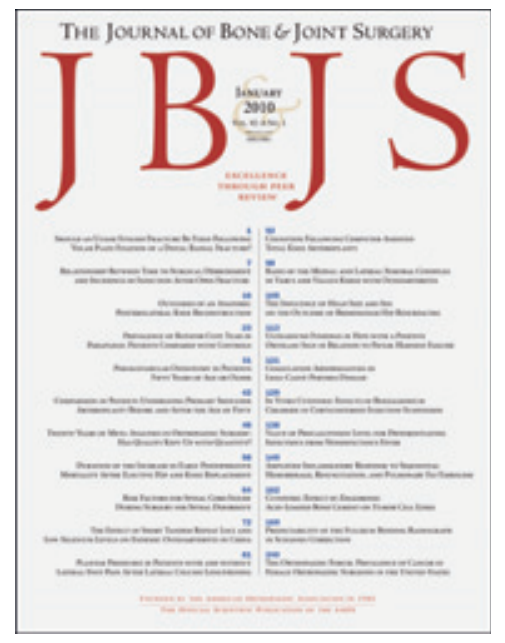

Artikkelen ble publisert i maiutgaven 2011 av tidsskriftet The Journal of Bone and Joint Surgery (www.ejbjs.org) 